\title{
From Summit to Tragedy: Sulayman Al-Bassam's Richard III and Political Theatre
}

\author{
GRAHAM HOLDERNESS
}

Richard III is one of Shakespeare's best-known characters, a familiarity independent of the history plays, Henry VI and Richard III, in which he appears. ${ }^{1}$ This celebrity has less to do with Richard's historical reputation, and more with the way in which great actors of the nineteenth and twentieth centuries gave the role status and popular visibility, particularly perhaps via Laurence Olivier's 1955 film version. ${ }^{2}$ Just as Hamlet is automatically identifiable by black suit and prop skull, Richard is immediately recognisable by his legendary deformity (mandatory hump, optional limp), and by the famous opening line of his initial soliloquy: 'Now is the winter of our discontent'.

The phrase has also, of course, escaped from Richard, as he escapes from the play: it was much used in Britain during the successive years of bitter labour dispute in the early 1970s, becoming inseparable from an environment of strikes, picket lines and power cuts. But it still belongs to Richard. When Peter Sellers guested on The Muppet Show, he delivered 'the soliloquy from Richard III' (with a distinct resemblance to Olivier), 'whilst (and at the same time) playing tuned chickens'. ${ }^{3}$

Spectators of Sulayman Al-Bassam's adaptation of Richard III, An Arab Tragedy, performed at the Swan Theatre in Stratford in February 2007, encounter from the outset an immediate disruption of convention and expectation, since the first person on the stage, the first to speak, is not Richard at all, but a woman, Queen Margaret.

- I am Margaret ...

... You needn't be concerned about me ...

... We lost ...

... It is your right to ignore me. I would ignore myself if my history let me ...

... I don't want your loans, your gifts, your reconstruction grants.

I don't want your pity ... 


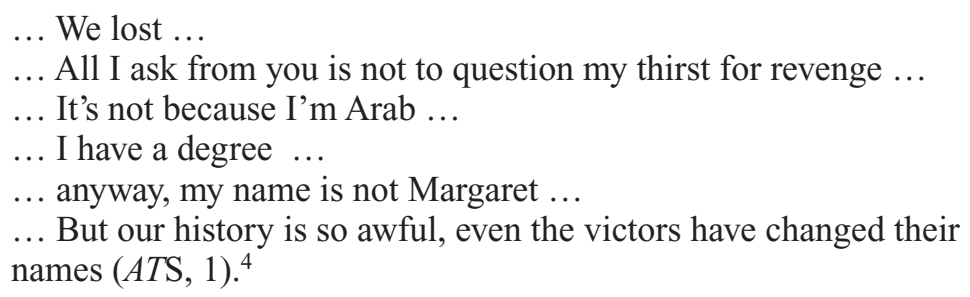

Margaret traverses the stage with a suitcase, which she opens and closes to reveal bundled clothes. ${ }^{5}$ She establishes an immediate link between the different 'pasts' of the play - c. 1400 and the early $1590 \mathrm{~s}$ - and the present. In the dimension of the play's historical subject, the Wars of the Roses, she is representative, as widow of Henry VI, of the defeated Lancastrian faction. In the late sixteenth-century domain of the play's composition, she speaks for vengeance, especially through the languages of revenge tragedy and witchcraft. But in the present of the spectator's existence, she is immediately identifiable as a refugee, dispossessed and rejected, ignored by history and the politics of power. Stateless, propertyless, abandoned, her suitcase contains the few belongings she has managed to keep with her. She has changed her name, lost her identity, and is insulted and patronised by the fake philanthropy of post-invasion reconstruction. But she retains enough pride to muster a fierce rejection of the audience's 'pity'.

Al-Bassam begins his play, then, not with a man, but a woman; with a woman who is not English, but declares herself to be Arab; not with a theatrical star, but with a marginal figure; and not with one of the victors who, in Walter Benjamin's formulation, normally have the privilege of writing history, but with one of the defeated. Expecting Richard III and 'Now is the winter of our discontent', the audience instead encounters a figure instantly recognisable as an Arab refugee, Lebanese or Palestinian or Iraqi, of the type who appears daily on our television screens. ${ }^{6}$ Although this is Shakespeare, she speaks Arabic, and the non-Arabic-speaking British spectator has access to her words only through translation. The Arabic text actually spoken by the actors was formed from Al-Bassam's English adaptation of Shakespeare's play; and the English surtitles read by the audience derived from the Arabic version (Al-Bassam adapted the play in English, then had it translated into Arabic, then produced an English version of the Arabic text to serve as the parallel English medium of performance). Languages divide and interweave, past and present 
diverge and assimilate, East and West are contrasted and temporarily merged. ${ }^{7}$ Is this here, or there? Now, or then ${ }^{8}$ Self, or other?

When Richard does speak, it is with an effect 'as strangely familiar as it is alien': 9

- The earth has changed its robes. The sorrows of winter and the cold bite of metal given way to the lazy warmth of spring ...

... War is too fat for its armour, too drunk to roar.

And all we hear today are the blasts of pleasure giggles,..

... Fighters who waged the valiant fight are seen today clean whiskered, soft skinned, slipping around in a lover's bed ...

... oiling whisper lusts with pleasure screams ...

... But I, whose chest is weighed with a weatherproof heart ...

... Dispossessed of a mug to draw a lusty female eye;

I, who was born to a mother with a narrow pelvis ...

... who spat me into this world so battered, beaten, buckled and underdone that even dogs bark at me! ...

... Therefore since I cannot prove a lover I am determined to prove a villain, ... (ATS, 1).

Please give line numbers for these quotations in note 10

In the Shakespearean 'original' of this speech, Gloucester's climatic metaphors are closely bound up with political references ('sun of York', 'clouds that loured upon our house'), ${ }^{10}$ and his discourses of war and peace are heavily influenced by the poetics of mediaeval chivalry and courtliness. In Al-Bassam's version, the metaphorical horizon has shifted. The images of seasonal change are more elemental and pastoral; the erotic fantasies more orientalised; and the personal conviction of physical difference localised into a different paradigm of gender and family relations ('born to a mother with a narrow pelvis' is quite different in its impact from 'deformed, unfinished, sent before my time'). Al-Bassam's Richard has neither hump nor limp, though he later protests a physical affliction symptomatised by a neck-brace concealed beneath his military uniform. Reviewers and spectators saw him as charismatically handsome rather than hideously deformed. The language is Shakespeare and yet not Shakespeare; classical and demotic; poetic and idiomatic; Eastern and Western. In Al-Bassam's initial adaptation text (ATT), the soliloquy was much closer to the Shakespearean 'original'.

\section{GLOUCESTER:}

The earth has changed its robes

The sorrows of winter and the cold bite of metal

Have given way to the lazy warmth of spring ... 


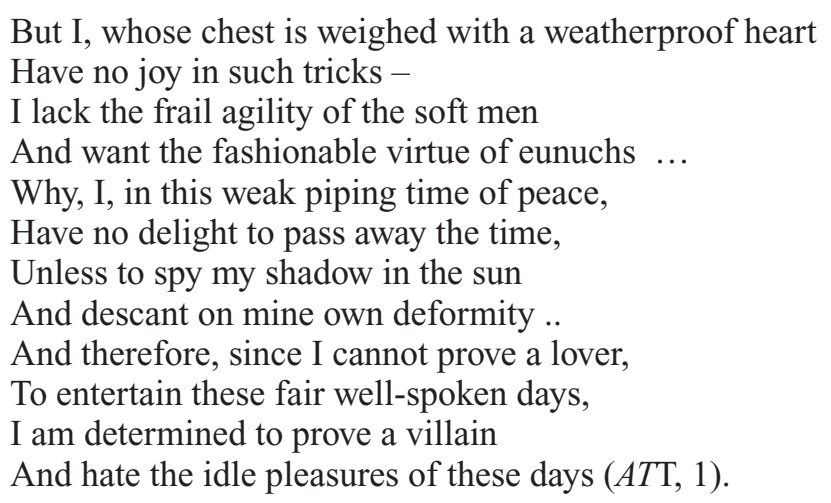

Here the modern, idiomatic and transcultural improvisations are cast into verse form, and modulate easily into a passage of unaltered Shakespeare. Al-Bassam preserves the Shakespearean rhythm with its effortlessly self-generating poetry, so that the decision to 'prove a villain' flows spontaneously from Richard's scholastic discourse. By the time the text reached performance it had been through what Al-Bassam calls 'a layered process of "arabisation" and reappropriation', ${ }^{11}$ and emerged as a dramatic medium with an entirely different rhythm and structure. In the ATS text Richard seems to tear his choice of villainy violently out of his complaint of deformity. There may be logic to this deduction, but it is the arbitrary logic of a megalomaniac will.

Al-Bassam has formally distinguished different conceptions of history at work in his play. Richard stands for a 'linear' teleology of history, planning, setting and seizing objectives, the iron will moving inexorably against obstacles to reach its targeted goal. Buckingham, Richmond and all the other political agents and instruments stand for an 'East-West' historical paradigm, still bifurcated by empire and its modern versions, history as manipulation and corruption, assassination and show trial. In Margaret, on the other hand, Al-Bassam saw a different kind of history: history as a cyclical recurrence, in which the past rises to meet the present, the dead wake, ghosts haunt the living, curses are efficacious and the passion of revenge never sleeps. ${ }^{12}$ A scene where Margaret casts bones to foretell the future symptomatises this history of omen and portent, the dark shadows of a buried past and an unrevealed futurity. ${ }^{13}$

Richard III: An Arab Tragedy represents Sulayman Al-Bassam's fourth Shakespearean experiment, and the third Shakespeare play he has adapted. Prior to his work on Richard III, he had written 
and produced an experimental improvisation on Macbeth, and three different versions of Hamlet. Hamlet in Kuwait, a version of Shakespeare's text performed in English, was initiated in January 2001, in association with a cultural festival 'Kuwait 2001: Cultural Capital of the Arab World', a historic celebration of national independence and autonomy which marked the tenth anniversary of Kuwait's liberation from the Iraqi invasion.

Born in Kuwait to a Kuwaiti father and a British mother, Al-Bassam was educated in Britain and now resides in Kuwait. He speaks Arabic and writes in English; his works are translated from English into Arabic by others, with his own participation. ${ }^{14}$ Al-Bassam's position within Kuwaiti society is that of a loyal citizen, but also that of an internal émigré, capable of viewing his country with a critical scepticism. He has expressed gratitude to the United States and its allies for the liberation of Kuwait in 1991, but offers an unqualified critique of U.S. foreign policy..$^{15} \mathrm{He}$ is committed to the cultural development of the Kuwaiti nation, but is also acutely conscious of the nation's need for radical political reform and cultural change.

Hence his Hamlet was reoriented to highlight social and political parallels. Claudius is the Arab despot, ruling over a corrupt oligarchy. The young prince, struggling to define himself in a hostile environment, suggests a disillusioned but resourceful younger generation, resistant to authority but diffident about the possibilities of action. The Ghost was a symbol of the Gulf War, a disturbing past that still haunts the people of Kuwait. The production was performed twenty times to capacity audiences, playing to a mixed audience of Arabic $=$ and English-speakers. ${ }^{16}$

In speaking of his decision to choose Shakespeare for this exercise, Al-Bassam focuses on the political parallels that can be drawn from the plays, and on the classic status of Shakespeare that provides a kind of shield or mask for the radical dramatist.

Shakespeare seemed a natural choice. In addition to being rich, malleable and volatile material, Shakespeare guaranteed me my 'green card' past the Cyclops of the state censor and the prejudices of a largely conservative society. ${ }^{17}$

To some extent Shakespeare was a 'Trojan Horse' for Al-Bassam, a cultural monument that enabled him to smuggle critical views on his own society past the authorities and to the greedy intelligences of the theatre audience. Hamlet in Kuwait 'encoded' its meanings 
within a Shakespearean register - 'a cultural encoding that would allow the work's meanings to override the various linguistic, cultural and political barriers in Kuwait and permit its meanings to explode in performance'. ${ }^{18}$

Al-Bassam's next Shakespearean experiment, entitled The Arab League Hamlet and first produced in Tunisia later in 2001, was an adapted version of the Shakespeare text, with scenes cut and rearranged, and the cast reduced down to a few principal players. The revised Jacobean text is punctuated with short scenes and interspersed lines in modern colloquial English. For the first time Al-Bassam used the 'summit' setting which added much to the success of The AlHamlet Summit. The characters occupied a space akin to a political assembly, sitting at and moving around desks and chairs. In this new staging all of the characters were visible all of the time. Projection screens displayed the larger context of 'an empire desecrated by war' and the characters 'adopted the grammar of diplomatic negotiations in a fight for their own survival'. ${ }^{19}$

The new setting threw the emphasis on explicit political parallels between the world of Shakespeare's court and the modern Arab world, and invited response as to a piece of political theatre.
The Kuwait experience had taught me that Arab audiences are very quick to extract political meaning from theatrical signifiers. In fact, as a result of decades of censorship, they had grown to almost demand political significance from 'serious' work. They enjoyed searching for it, hungrily reading metaphors into scenes and digging for signs of dissent in the work - sometimes finding it where there was none intended! ... I was actively feeding the Arab audience's hunger for political statement and controversy. Indeed, audiences and critics in Tunisia immediately read the work as a piece of radical agit-prop. ${ }^{20}$

When The Arab League Hamlet was performed to an invited audience in London it was far less successful. In Al-Bassam's view this was because while the Arab audiences were skilled in reading political meaning from dramatic texts, and saw the play as 'a politically hyper-loaded piece that touched at the very heart of their feelings of despair in the political process', the Western audience 'regarded it as little more than a "clever" adaptation of Shakespeare'. 'The political overtones did not translate'. ${ }^{21}$

In fact it is far more likely that English spectators encountered the 'political overtones' not as indecipherable but as all too familiar. A 'clever adaptation of Shakespeare' using modern dress and settings, 
insistently contemporary parallels and back-projected newsreel footage is something of an everyday occurrence in U.K. theatre. When Peter Culshaw saw The Arab League Hamlet he had no problem in reading this dimension off the very surface of the production:

The Hamlet I saw in London began with the characters seated behind desks as though at a summit, complete with name tags and headphones. This set the scene for an evening of power struggle, negotiations, compromise and tragic chaos. The overheated, incestuous atmosphere built up ('something rotten in the state of Denmark') with Claudius as a western puppet and

Wording sounds a bit awkward?
Al-Bassam was correct, however, in surmising that the production took the British audience into Shakespeare rather than into Arab culture and psychology: 'I had wanted to put the English-speaking spectator inside the head of the Arab spectator in Kuwait and Tunisia ... . I had wanted the English spectator to experience the same sense of strangeness in familiarity the Arab one had felt and, above all, the same degree of implication in the events presented to them on stage'. But The Arab League Hamlet simply did not provide the Western spectator with a theatrical language powerful and suggestive enough to facilitate that cultural leap into such unfamiliar territory. 'I was wrong'. ${ }^{23}$

The Al-Hamlet Summit was first performed in English as part of the Edinburgh International Fringe Festival, in August 2002. The newly modernised English script, combined with the political assembly 'summit' setting devised for The Arab League Hamlet, played naturally into the category of political theatre. Al-Hamlet is, if anything, more overt in its agit-prop relevance and immediacy than its predecessors. Peter Culshaw said that it 'makes explicit what was implicit' 24 in The Arab League Hamlet. Al-Bassam identified the play's themes as 'political corruption, the twisted relationship between willing puppets and their imperial masters, the rising tide of Islamic fundamentalism; suicide as a desperate form of political selfexpression'. ${ }^{25}$ The parallel between Claudius and Saddam Hussein was further exaggerated; Ophelia is more closely linked to the Palestinian cause; and Hamlet himself more decisively characterised as an Islamic fundamentalist, goaded to violence by internal betrayal rather than by external aggression.

This emphasis on specific contemporary political issues offers the play to audiences as a piece of dramatic journalism, or a roman-à-clef 
from which obvious contemporary analogues to the Shakespearean characters can readily be identified. This is exactly how the play was read by many spectators:

Polonius is a devious spin-doctor, Hamlet moves from indecision to becoming a Bin Laden-type religious fanatic, while Ophelia ends up as a suicide bomber. CNN-type footage of burning oil wells adds to the claustrophobia. ${ }^{26}$

Hamlet becomes a religious extremist ... Laertes joins the army ... Ophelia is a suicide bomber. ${ }^{27}$

Although the primary historical context of the adaptation is that of the invasion of Kuwait and the Gulf War, it was clearly also influenced by the atrocity of $9 / 11$, and this helped Western viewers to find paradigms for understanding it: 'the play rides on the aftermath of September 11 2001, and the impact it had on Arab and Western perceptions of one another'. ${ }^{28}$

It is abundantly clear that Al-Bassam was trying to do something more than this. These quotations suggest that Western spectators of The Al-Hamlet Summit are impressed primarily with the way in which the play brings Shakespeare up to date, providing dramatic analogues for contemporary archetypes or stereotypes (the Arab dictator, the Islamic fundamentalist, the suicide bomber) that are visible daily on every television screen. But Al-Bassam wanted to move the spectator away from these temptingly easy analogies. The most substantial difference between The Arab League Hamlet and The Al-Hamlet Summit is that in the latter Al-Bassam deviated from the Shakespearean text and produced a wholly new script combining a much wider range of linguistic and theatrical registers. These naturally include echoes of Shakespearean verse and the modern colloquial language of a contemporary-oriented political theatre, but also new layers of poetic language derived from classical Arabic, including the Holy Quran, from contemporary Arabic poetry, and from a crosscultural poetic sensibility capable of interweaving all these strands and producing from them a new theatrical discourse.

These features are more noticeable in Al-Bassam's most recent Shakespearean adaptation, his version of Richard III, which was premiered at the Royal Shakespeare Theatre in Stratford as part of the RSC's 'Complete Works' project. The repertory consisted of 'mainstream' productions and parallel or alternative versions 
('responses'). An Arab Tragedy was billed as a 'response' to Michael Boyd's production of Richard III. The play was performed in Arabic (the first play in Arabic to be produced by the RSC), with the English text projected onto screens as surtitles, and with some scenes spoken in English. This piece clearly has a longer development history that remains in process: it was played in Athens in May 2007 as part of the Athens Festival, and is scheduled to play at the Bouffes du Nord in Paris, and thereafter in Amsterdam.

Although the play is set in an unnamed 'Gulf state', Al-Bassam clearly did not want the play's frame of reference restricted, as some reviewers suggested it was, to the Gulf monarchies. Hence he broadens the scope of the piece to include the whole Middle East:

Please supply a reference for this extract.

\begin{abstract}
More generally, the modern Middle East, like so many of Shakespeare's tragedies, offers a painful plethora of examples of how not to rule. Modern imperialism, tyranny, barbarism, oppression, plots, assassinations and civil wars are sadly becoming the rule not the exception in our region. The players in this grim game of politics, natural resources and strategic power are many, and like all the characters in Richard III, none are innocent; all have bloodied their hands.
\end{abstract}

At this point we are still inside the paradigm of agit-prop theatre occupied by the earlier adaptations. Here the landscape of the play is identical to the landscape of the modern Middle East, Shakespeare is our contemporary, and history is politics.

It is true that the play does to a certain degree depend on relatively simple parallels between Shakespearean situations and characters, and those to be found in Al-Bassam's contemporary Middle East. This dimension was certainly the primary focus of the play's British reception, intoxicated with orientalism:

It is as though the Swan Theatre has been put on a magic carpet and flown to Saudi Arabia. For the gripping two-hour direction of Sulayman Al-Bassam's 'Arabian' account of Richard III, we see not dukes, earls and queens, but turbaned sheiks and women in burkas. We hear not alarums but strange beguiling ululations. Shakespeare's language comes to us as though through secret service intercept: in Arabic with surtitles. ${ }^{29}$

The same reviewer saw the piece as a play of 'urgent topicality', 'reconceiving Shakespeare's tragedy for the jihadi age'. Shakespeare's play is ripe for such analogies, replete as it is with arrests and executions, secret assassinations, political in-fighting and photo 
opportunities, hostage-taking, character assassination and show trials, religious hypocrisy, forced confessions, usurpation, invasion and civil war. All these aspects of the plot are here 'Arabized' and transferred to the play's 'unnamed oil-rich kingdom or emirate'. ${ }^{30}$

The staging accentuates these parallels further. Just as in Hamlet in Kuwait, projection screens were used to contextualise the action to the Gulf War, so in An Arab Tragedy back-projected images flesh out the contingent context of despotism, military action, clandestine surveillance. 'Grainy video footage of forced confessions and executions jostle for attention with swaying figures.' 31 These 'multimedia interventions' ${ }^{32}$ were read primarily as documentary illustrations enforcing the contemporary parallels. Al-Bassam's Buckingham is a double agent, secretly liaising with the Americans as he ostensibly supports Richard's bid for the throne. The screens record his coded email communications. 'Even as Buckingham does Richard's bidding, he sends e-mail updates on the sly to the American ambassador, reporting on the latest political machinations', ${ }^{33}$ Richmond is portrayed as a 'platitude-spouting Christian US general who at the play's conclusion announces the installation of an interim government'. ${ }^{34}$ Stability is already however threatened by insurgency:

Richmond is an American general who, chillingly, speaks the final words of the play in English, with the swaggering accent of the occupying army. The speech, ending with the words 'God say Amen', is meant to reassure. But even as he delivers it, a group of insurgents can be seen in the background, ready for a fight in the name of their own religion, 'Allah-u akbar!' they cry. 'God is great!'35

At this final point of the drama, just before the theatre collapses its illusions and decants us back out into our own world, we are here transported from 1400 to 2003, from Bosworth Field to Afghanistan or Iraq in the embattled Middle East of the twenty-first century.

I would nonetheless argue, and will seek to illustrate from some moments from the play, that the true achievement of An Arab Tragedy lies less in its astute political parallels and historical comparisons, and more in the crosscultural encounters it sets up between Western and Arab societies. The project was initially entitled Baghdad Richard (tickets were sold for the play under that title) with the GloucesterSaddam parallel clearly foregrounded. Al-Bassam changed the title in response to changing events, particularly the trial and execution of 
Saddam, but also out of a realisation that in this theatrical medium, oversimplification is a constant danger.

With the rapid change of events in the region and also as I delved more deeply into it to make that comparison really work, I reached the conclusion it would be selling both histories a bit short in trying to make a foolproof comparison between Richard III and the rise and fall of Saddam Hussein. ${ }^{36}$

The new title, An Arab Tragedy, suggests a broader territory, not just Iraq, and broaches wider issues of concern to the Gulf States and the Arab world in general. Al-Bassam came to see the play as initially about 'constitutional crisis' which is a 'very current' issue for the Gulf region. The production programme quotes a passage from the fourteenth century Arab historian Ibn Khaldun on the dangers of dynastic succession in monarchy. The succession of a child protected by powerful 'wazirs' renders the state vulnerable, and this weakness is seen as a virtually incurable 'disease of dynasty'. ${ }^{37}$ In a programme note Al-Bassam underlines this parallel:

In this piece, I am using a foreign (English) history to explore contemporary political anxieties in the Gulf and Arab region. The monarchical system of rule that governs all the countries in the Arabian Peninsula (in which the reins of power are passed down through generations descended from an original founder) has proved itself to be a stable and durable form of governance. But, as recent events have shown, crises of succession present a constant threat of implosion to these monarchies. Richard III offers the model of a crisis of succession that turns into a nightmare. ${ }^{38}$

This theatrical 'nightmare' goes well beyond the interpolation of agitprop relevance, and has the capacity to take the spectator deeper not only into Arab culture, but into territories of myth and communal emotion where transcultural rapprochements can more effectively take place.

Shakespeare's Act 1, Scene iv is the long scene of Clarence's murder. Clarence tells Brakenbury of the dream which anticipates his assassination. In the dream Clarence finds himself in the underworld, and is rebuked by the ghosts of his victims for his crimes of perjury and murder. The murderers then enter and engage in some clowning before falling to their task. Clarence cannot believe that Edward would wish him killed, protests his innocence and appeals to shared Christian values: 
I charge you, as you hope to have redemption

By Christ's dear blood shed for our grievous sins, That you depart, and lay no hands on me.

There follows an energetic debate on the authority of kingship vis-àvis God's law; whether or not the guilty have any rights to mercy; the proper punishments for perjury and murder. Eventually the murderers confide in Clarence the truth that they act for Gloucester. He pleads for his life, and they kill him by beating him and drowning him in the wine-butt.

Al-Bassam concentrates this whole sequence down to this:

- I swear there is no God but Allah.

God forgive my sins.

... In God's name what art thou?

- A man as you are.

- If you be hired for money go back again and I will send you to my brother Gloucester ...

... He shall reward you better for my life than the King does for news of my death.

- You are deceived, he hates you.

- Do not slander him.

He is kind and merciful.

- Merciful as rain on mud huts. He sent me to slaughter you. Pray now for you must die.

- Dare you counsel me to pray to God yet would war with God by murdering me?..

... He who kills without due reason, it is as though he kills the whole of humanity (Q.);

- Pray!

- And do not shed blood that is sacred by Allah's law (Q.);

- Pray!

- Al Rawandi in the sources says: beware of shedding innocent blood-

- Pray!

- Pray! (ATS, 7).

Here Clarence is presented as a devout Muslim who quotes the Holy Quran and illustrations from Islamic scholarship against unlawful killing and the violation of innocence. Not surprisingly there is no wine-butt: instead Clarence is drowned in the sacred water he has used to perform his ritual ablutions. Simultaneously the musical accompaniment deploys an old Gulf sea-song, thus invoking poetic associations of dreaming and drowning. 
Al-Bassam has moved the narrative of Clarence's dream from this scene to an earlier scene with Richard. In the murder scene there is no detailed account of Clarence's past, or the role he has played in previous political machinations: he seems an ordinary pious man who is conscious of his sins, and prays for forgiveness. His appeal to his murderers is articulated in terms of the Islamic values they share, just as, in Shakespeare, Clarence appeals for mercy through the blood of Christ. ${ }^{39}$ The Quaranic quotations used by Clarence speak out against the murder of innocence, and the reference to "the shedding of innocent blood' invokes the tradition of Ibrahim and Mohammad, the young sons of Muslim and the descendents of the Prophet, who were assassinated in a story that forms a direct and detailed parallel to the story of the princes in the tower. ${ }^{40}$ Thus Clarence as victim is shifted closer in this version to the massacre of the innocents later practised on young Edward and Richard. ${ }^{41}$

In Shakespeare's scene, Clarence's Christian language is undermined by the murderers' indictment of his crimes. Here, however, the issue is not Clarence's guilt - for who is guiltless? - but the moral atrocity of assassination itself. The murderers instruct him to pray, although his prayers clamour out against their actions. They decline to enter any kind of religious debate with him, thus letting the stark moral beauty and clarity of the Quranic injunctions stand in clear contrast to the act of butchery perpetrated by those who purport to share their victim's faith. This is more than a substitution of an Islamic for a Christian frame of reference. This is an attempt to draw the spectator inside an engaged but critical perspective on Islam and the violence that shadows it.

Later in the equivalent of Shakespeare's IV.iii, in which Tyrrel describes his murder of the princes, we are presented again with the immense moral power of religious taboo, and the strength required to betray it:

- I swear I turned back twice.

But he put out his hand. The Book was on the pillow ...

... "No!" I said. It's the Quran. It's haram. Can't do it. Haram ...

... Then one of them opened his eyes: a boy. Same age as my own boy.

Haram ...

... God, what did you make me of ? I killed my friend, then these

children ...

... Filthy dirty scab, rotten useless chump ...

... It was not me: it was

the Devil. Not me: the Devil put out his hand. 
... Damn you and damn who asked for your love. Damn lovers that seek only pain!.

... My crime in this life was placing you in my heart. To love one like you is to slash open my veins (ATS, 21).

Here it is Catesby, no stranger to violence, who undertakes the murder on Richard's behalf. In Shakespeare on the pillow there lies a 'book of prayers', here replaced by the Holy Quran. The sight of the text forces Catesby to realise that he is about to commit an unspeakable crime, 'Haram'. The Arabic word haram can mean 'forbidden' or 'sacred'. It is used for example of sanctuaries and holy places such as the Musjid-al-Haram at Mecca, an inviolable sacred space. Catesby rehearses in Islamic language and terminology the power of the sacred law that forbids the desecration of innocence; the immense struggle of the man who seeks to betray the law; and the desperate invocation of a diabolical power to explain how such acts can be committed. The speech ends by quoting a traditional Arab lament which sings of the hopelessness of love, the bitter disenchantment of a betrayed loyalty.

My final illustration is from the conclusion to Arab Tragedy, which aims for effects quite different from those of the source text. Just as the play opened by countermanding conventional expectations of Richard's famous soliloquy, so here there is no trace of the scene in Richard's camp on the night before Bosworth: no ghosts of the slain returning to haunt him, no lights burning blue, no self-pitying exhortations (to the manifest disappointment of some spectators). The equivalent of Richard's last Shakespearean soliloquy is this oneended telephone conversation Richard conducts with the American Embassy:

\footnotetext{
- [Prayer] Please Allah forgive my deepest blackest sins, my crimes. My soul this night is heavy, my life in your hands...

Why is $\quad-$ [Telephone] Will the Ambassador not speak to me? I have a extract in conscience I want to talk to him about, ... learning!..

... Where can I take this stray dog of mine? Where can I kennel it? If my dog bites you Ambassador ...

... it will infect you and your masters, show you in the filth I know you!..

... I have studied how to plant bombs in the bowels of your democraciesyour hands are not clean, sir, I will unveil your complicity!..

... Neither are my hands clean but I don't boast otherwise you two-faced hypocrite democrat dog!..
} 
... Now be careful what you say Ambassador you're in my country. Oh really? Well, I have firing squads in the Hague too! (ATS, 24).

Again the language of Islamic prayer provides the discourse for Richard's expression, whether genuine or merely conventional, of guilt. ${ }^{42}$ If he genuinely does want to discuss his guilt with the ambassador, the intention very soon evaporates as Richard collapses from one raging diatribe into another. The self-searching renaissance hero-villain is replaced here by the modern megalomaniac despot, psychotically convinced of his power, unscrupulous in the pursuit of his will, ruthless in meeting opposition. There can be no sympathy for such a figure, and Al-Bassam has stated that he deliberately omitted Richard's final soliloquy because in this context he 'questioned the value of pity'. ${ }^{43}$ The subsequent entry of Margaret, leading a procession of the dead, creates what Al-Bassam calls a 'religious-politicalhistorical montage', underscored by Catesby's recited prayers, which draw on litanies from both the Shia and Sunni traditions. ${ }^{44}$

Having defeated expectation so many times, Al-Bassam finally obliges by providing Richard with the 'horse' for which he would exchange his kingdom. On stage this is a strange contraption, part gym equipment and part physiotherapy apparatus, that is brought in disguised and then revealed when required. Richard mounts it and tries to flog the machine into action, brandishing the scimitar:

- What's this horse called?

- 'Al-Umma'.

- 'Al Umma'! Let me ride you! O my battle of Badr! ... Victory sits on our helms (ATS, 25).

'Al-Umma' is 'the nation of believers', the people considered as a belief community. The word is encountered widely in Arab culture, in political language (the Kuwaiti parliament is called 'Majlis-alUmma'), in the press, where it is the title of several newspapers, or as the name of an Islamic fundamentalist group. Richard is offering himself as the leader of an Arab Islamic nationalism. The battle he names, Badr (625) is a great victory from the history of militant Islam. When Richard III's iconic lines finally arrive, they can be read as the echo of an ancient and suicidal heroism that can still be invoked in the present: 'A horse! A horse! / My kingdom for a horse!' (ATS, 25). But the heroism is undermined by the absurdity of the stage 
image, Richard flailing clumsily around on a mechanical horse that is going nowhere except in circles.

In the adaptation text (ATT), Richard used the name of another battle, Qadisya (636), in which the Muslims defeated the Persians. Al-Bassam dropped this reference, since to Arab spectators it would tie Richard too closely to Saddam Hussein (Saddam invoked this historical exemplar in the course of his war against Iran of 1980-198, known as the Qadisiyyat Saddam). 'Badr', the battle of 625 in which a small Muslim force defeated the much larger army of the Meccans, also invokes Saddam, but with deeper crosscultural reverberations and sharper ironies. The eighth sura of the Holy Quran represents the Battle of Badr as clear proof of God's favour to believers. The chapter is called Al-Anfal, 'The Spoils'. ${ }^{45}$ Saddam used the title Al-Anfal as the code name for his notorious campaign against peshmerga rebels and Kurds between 1986 and 1989, the campaign in which chemical weapons were used against civilians. Saddam's cousin 'Chemical Ali' was sentenced to death on charges including these atrocities.

Hence the play's emphasis shifts from any notion of Richard as victim, to the list of martyrs with which the play closes. This list, which fades out as if it could go on indefinitely, is the equivalent of a Shakespearean list of battlefield slain, but brings together Arab martyrs past and present, from the dawn of Islam to today; brings together soldiers, writers, thinkers, freedom fighters of all descriptions, and victims of may different regimes. Their names echo into silence as the territory of the stage splits into civil war between occupying power and insurgent militia.

These examples should help to further the argument that although Al-Bassam's adaptations of Shakespeare clearly are a form of political theatre, and offer themselves to be read as such, they are not restricted to this cultural register. The works aim to produce 'a richly suggestive theatrical experience, not a piece of agit-prop' ${ }^{46}$ Political parallels and historical comparisons are certainly drawn, but not in any simplistic or reductive way. Rather he attempts to 'put contemporary figures in the political landscape, within the fabric of another world, a Shakespearean world, and thereby open up a space for dissent, or a space for another kind of annotation'. ${ }^{47}$ The Shakespearean dimension is there to provide a dramatic space in which contemporary events can be reprojected with something like Brecht's Verfremdungseffekt, so that the present condition is estranged rather than simply recognised. 'Current political events - and our 
perceptions of them - hang like a misty landscape, half-perceived, in the backdrop of the play' ${ }^{48}$ Al-Bassam wants his Western spectators to think again about contemporary political stereotypes rather than merely to identify (and implicitly endorse) them.

Please supply a reference for this extract.
In making theatre in the Arab world and presenting it to the West (as is the case in this production) I am very conscious of not using theatre to make binary moral statements (we are right: you are wrong) as this process merely confirms prejudices and makes matters worse. I have tried to level the earth to make a space for this text and aspects of the contemporary Arab world to meet and make sense of each other.

The dramatist was also obviously steering a difficult course among a wide range of extreme and moderate opinions on the current condition of the Middle East. His focus is on the possibilities for crosscultural linguistic and theatrical encounters, and for enhanced understanding between divided communities.

I think that there are sadly few Arab voices that are able to speak to Western audiences outside of a political or religious context and in that sense one has to find a way to steer between ideological cliché and antagonism but also to use those elements - because that's what most people are familiar with - to open up new space for dialogue and meeting. ${ }^{49}$

The last word belongs to the actor who played Richard in the production, Syrian Fayez Kazak, who told an interviewer:

Whenever I sing you my song, and you sing me your song, then we become relatives on this earth. Otherwise we will be enemies. ${ }^{50}$

\section{Notes}

1. I am very grateful to Sulayman Al-Bassam and Margaret Litvin for their invaluable assistance with this article.

2. 'Richard III is comfortably the most entertaining of the three great Olivier Shakespeare films, and may have done more to popularise Shakespeare than any other single work. When shown on U.S. television that same year, the resulting audience (estimated at between 25 and 40 million) would have outnumbered the sum total of the play's theatrical audiences over the 358 years since its first performance'. Michael Brooke, 'Richard III', Screen Online (London: BFI, 1955) [Available at $<<\mathrm{http} / /$ www.screenonline.org.uk/film/ id/467017/index.html $>>$ (accessed 12 July 2007). Sellers also did a Richard III version of the Beatles' song Hard Day's Night in a direct imitation of Olivier's film. 
3. Roger Lewis provides a fascinating parallelism between Sellers and Olivier in his The Real Life of Laurence Olivier (London: Arrow Books, 2007 [1996]), 1-19.

4. Two texts are used as a basis for this article, both kindly supplied by Sulayman AlBassam. The first, styled here 'Arab Tragedy Text' (ATT) is an adaptation into English, partly free and partly imitative, of the Shakespearean text. The second, 'Arab Tragedy Surtitles' (ATS) is a text representing the English surtitles as they appeared on video screens in the performances at Stratford-upon-Avon in May 2007. According to a programme note, 'The surtitles you are reading at times paraphrase the original English and at others try to capture the texture of what is being said in Arabic' (Royal Shakespeare Company programme, The Culture Project [Kuwait]) and Sulayman Al-Bassam Theatre, William Shakespeare Adapted by Sulayman Al-Bassam, Richard III: An Arab Tragedy [2007]). The two texts are very different, and reflect the complex process of adaptation. ATT is divided into scenes corresponding to the Shakespeare text, while ATS takes the form of blocks of text designed to fit into PowerPoint slides. Quotations here refer to page numbers on printouts from ATT and ATS.

5. Sam Marlowe saw these clothes as 'the gore-stained garments of her slaughtered husband and son'. The Times, 15 February 2007.

6. Dominic Cavendish complained, "one may baulk at the way that "Now is the winter of our discontent" has been twisted into "The sorrows of winter and the cold bite of metal ..." ". In this reviewer's opinion Al-Bassam has 'duffed up the original text to the point of unrecognisability'. 'Putting the Sheikh Into Shakespeare', The Telegraph, 15 February 2007.

7. 'His play blends past with present, East with West.' Hussain Al-Qatari, 'Kuwaiti Playwright Advocates Cultural Reform', Kuwait Times, 8 May 2007.

8. Dominic Cavendish describes it as a 'collision between past and present' ('Putting the sheikh Into Shakespeare').

9. Ibid.

10. I use the word 'original' very advisedly, here meaning the speech as it appears in the published texts of 1597 and 1623.

11. Personal communication from Al-Bassam to the author (5 May 2007).

12. The linear and cycical motions of history nonetheless interact. Al-Bassam thinks of Richard as a 'product of endless cycles of violence, revenge and civil war'. Quoted in 'Shakespeare's Tragedy in Arabic', Trade Arabia News Service, 24 January 2007.

13. Observations made by Sulayman Al-Bassam in a staged discussion with Michael Boyd, Playing with History, Swan Theatre, Stratford-upon-Avon (February 2007).

14. See Sulayman Al-Bassam, The Al-Hamlet Summit (Hatfield: University of Hertfordshire Press, 2006), 25. Mehdi Al-Sayigh was credited as 'Translator' for Richard III: an Arab Tragedy.

15. Al-Bassam says 'As a Kuwaiti, there is a lot I owe to the coalition', quoted by Peter Culshaw, 'Shakespeare and Suicide Bombers', Daily Telegraph, 1 March 2004. But elsewhere he speaks critically of 'America's War on Terror'. See Sulayman Al-Bassam, 'Director's Note - Hamlet In The Age of Infinite Justice', The Arab League Hamlet. Available at $<<$ http://www.zaoum.com/index.html $>>$ (accessed 15 May 2007). In Arab Tragedy 'War on Terror' is a slogan adopted by Richard and Buckingham as a pretext for repression.

16. 'Hamlet in Kuwait'. Available at $<<$ http://www.zaoum.com/ $>>$ (accessed 15 May 2007). 
17. Sulayman Al-Bassam, 'Am I mad? Creating The Al-Hamlet Summit', Theatre Forum 22 (Winter/Spring 2003), 85-68.

18. Ibid., 86 .

19. Ibid., 86 .

20. Ibid., 86 .

21. Ibid., 87.

22. Culshaw, 'Shakespeare and Suicide Bombers'.

23. Al-Bassam, 'Am I mad?', 87.

24. Culshaw, 'Shakespeare and Suicide Bombers'.

25. Al-Bassam, 'Am I mad?', 87.

26. Lynn Gardner, 'The Al-Hamlet Summit', The Guardian, 13 March 2004.

27. Maddy Costa, 'The Al-Hamlet Summit', The Guardian, 13 August 2002.

28. 'Hamlet Bin Hamlet: Sulayman Al-Bassam Fuses Shakespeare with the Middle East', in Emerging Kuwait 2006 (Oxford: Oxford Business Group, 2006), 205.

29. Cavendish, 'Putting the Sheikh into Shakespeare'.

30. 'Note on the Production', in RSC programme, 2007.

31. Marlowe, The Times, 15 February 2007.

32. Kieron Quirke, 'Shakespeare's Arabia', Evening Standard, 14 February 2007.

33. Sarah Lyall, 'Political Shakespeare: an Arab Richard III', International Herald Tribune, 21 February 2007.

34. Marlowe, The Times, 15 February 2007.

35. Lyall, 'Political Shakespeare: an Arab Richard III'.

36. 'A Tale of Two Richards: Terry Grimley Meets Sulayman Al-Bassam and Talks to Michael Boyd About Two Contrasting Takes on Richard III', Birmingham Post, 2 February 2007. Elsewhere he described the initial plan to parallel Richard and Saddam as a "nonsequitur' (quoted in Lyall, 'Political Shakespeare'), and also talked of the risk of 'trivialising the horrors' of the Saddam regime, (quoted in 'Politics Gets a Shakespearean Twist at London Theatre', The Peninsula [Qatar], 2 December 2007).

37. Ibn Khaldun (1332-1406), Arab Muslim scholar. His major historical work is entitled Please Please Book of Evidence, Record of Beginnings and Events From the Days of the Arabs, Persians give give full and Berbers and Their Powerful Contemporaries. See Ibn Khaldun, The Muqaddimah, ed. place of forename(s) N.J. Dawood, trans. Bruce Lawrence (Bollingen Series, 1969). As Al-Bassam has observed publication of editor to me, Khaldun was contemporary, not with Shakespeare, but with Richard III.

38. RSC programme, 2007.

39. 'All the Christian elements have been uprooted and replaced with Islamic references ... it is a political play, but it happens in a very religious context ... a secular, western audience would normally see that in a very historical way, but this way it becomes contemporary'. A1Bassam quoted by Peter Aspden, Financial Times, 6 February 2007.

40. The mausoleum of the Sons of Muslim can be seen at in Moosayab near Karbala in Iraq.

41. There are many resemblances between the two stories, which clearly have deep folk-tale roots. The Sons of Muslim are held in a dungeon; the sight of them praying together moves the jailer so much he releases them; they are killed successively but remain united in death.

42. 'In the use of recitations and quotations from the Holy Quran we have sought to portray different aspects of the political, military and social functions to which religion is put in the contemporary societies of the Gulf. It is a bitter truism that Islam is, at times, misused 
by authority; the words and meanings of the Holy Quran are perverted to serve agendas of power. In dramatising this reality we offer a pious critique of our world that, one trusts, will not be misunderstood'. 'Note on Use of Quranic Extracts', in RSC Programme, 2007.

43. Observations made by Sulayman Al-Bassam in a staged discussion with Michael Boyd, Playing With History, Swan Theatre, Stratford-upon-Avon (February 2007).

44. Personal communication from Sulayman Al-Bassam, 25 July 2007.

45. The Koran, trans. Arthur J. Arberry (Oxford: Oxford University Press, 1983), 16978.

46. Patrick Carnegy, 'Dynastic Dissonance', The Spectator, 24 February 2007.

47. 'Sulayman Al-Bassam Interview by Gabriel Gbadamosi', Night Waves, Radio 3, broadcast 9 May 2006.

48. Sulayman Al-Bassam, 'Author's Note', in The Al-Hamlet Summit (Hatfield: University of Hertfordshire Press, 2006), 25.

49. Quoted by Sebastian Usher, 'Shakespeare in Arabic Hits Stratford', BBC News Front Page (19 February 2007). Available at $<<$ http://news.bbc.co.uk/1/hi/world/middle east/6375547.stm $>>$ (accessed 15 May 2007).

50. Fayez Kazak, quoted in 'A Tale of Two Richards'. 